Environmental Monitoring and Assessment, Volume 191, Issue 7, July 2019 Article number 470

\title{
Estimation of particulate matter and gaseous concentrations using low cost sensors from broiler houses
}

\author{
Roheela Yasmeen ${ }^{1,2}$, Zulfiqar Ali², Sean Tyrrel ${ }^{3}$, Zaheer Ahmad Nasir ${ }^{3}$ \\ ${ }^{1}$ Lahore Garrison University, DHA Phase VI, Sector C, Lahore, Pakistan \\ ${ }^{2}$ University of the Punjab, Lahore, Pakistan
}

${ }^{3}$ School of Water, Energy and Environment, Cranfield University, Cranfield, MK 43 0AL

Corresponding author email: raheelasattar44@gmail.com

\begin{abstract}
Particulate and gaseous emissions from intensive poultry facilities are major public and environmental health concern. The present study was aimed at exploratory monitoring of particulate matter (PM) and gaseous concentrations in controlled-environment facilities using low-cost sensors in Lahore, Pakistan. The indoors and outdoors of 18 broiler houses, grouped into three categories based on the age of birds: group I (1-20 days), group II (21-30 days) group III (31-40 days) were examined. Low-cost sensors Dylos 1700 and Aeroquals 500 series with different gas sensor heads were used to monitor PM and different gases such as nitrogen dioxide $\left(\mathrm{NO}_{2}\right)$, hydrogen sulphide $\left(\mathrm{H}_{2} \mathrm{~S}\right)$, carbon dioxide $\left(\mathrm{CO}_{2}\right)$ and methane $\left(\mathrm{CH}_{4}\right)$ respectively. Overall, the mean PM and gaseous concentrations increased with the age and activity of birds as compared with the non-activity time of birds. Statistically significant differences were observed in all measured parameters among the groups. The negative correlation between indoor and outdoor environments for PM and gas concentrations at some broiler houses demonstrates the contribution of additional sources to emissions in outdoor environments. The findings contribute to our knowledge of temporal characteristics of particulate and gaseous concentrations from poultry facilities particularly in Pakistan and generally to the capability of using low-cost sensors to evaluate emissions from such facilities.
\end{abstract}

Keywords: Poultry facilities, Controlled environment, PM, Gases, Low-cost sensors 


\section{Introduction}

There has been a steady increase in intensive agricultural practices such as poultry production to meet the food demands of a growing population worldwide. Simultaneously, concerns about emissions (including dust, gases and bioaerosols) from such controlled environment facilities are increasing particularly environmental, climatic and public health impact Witkowska and Sowinska (2017). According to one estimate in all agricultural practices in Europe, intensive poultry is contributing almost $50 \%$ of total particulate matter (PM) emissions (Emep-Corinair 2007). Evidence is increasing on the potential impact of the emissions from these facilities for example, for occupational exposure (Portejoie et al. 2002; Kocaman et al. 2005), vegetation stress, reduced visibility, odour and organic dust (Pope et al. 2002; Mostafa and Buescher 2011; Chen et al. 2014) and communities living in close proximity to these facilities (Mitchell et al. 2004; Hinz et al. 2008).

The typical sources of airborne dust in poultry facilities are feed, bedding material, bird's droppings, bird's age and bird's down feathers (Vučemilo et al. 2008; Cambra-Lopez et al. 2011). However, van Harn et al. (2012) have reported that bedding material has no effect on $\mathrm{PM}_{10}$ concentrations while the age of birds adds a $4.8 \%$ increase in PM mass concentrations. The particulate fraction of emissions can be composed of feed, feathers, dried faecal matter, bacteria, fungi, moulds, endotoxins, pollens, animal dander, various enzymes, infectious agents (Witkowska and Sowińska 2017). Hence, particulate emissions can vary in size and chemical composition (Cambra-Lopez et al. 2010a, b). Studies have shown that particulate emission from these facilities is mostly coarse, primary in origin, and organic in nature, adsorbs various gases and odours and has microbes and their metabolic compounds (Donham et al. 2000; Radon et al. 2001; Donham et al. 2002; Homidan et al. 2003; Cambra-Lopez et al. 2010a, b). The sources of microbes in these facilities are birds, feathers, faecal material, litter, feed, employees and air. The poultry facilities are also a rich source of gaseous emissions, and according to Broucek and Cermak (2015), the gaseous emissions depends on various factors such as decompositions of faecal matter, number of birds, movement of birds and ventilation rate. However, management practices, temperature, humidity, building age and ventilation rate also play a role (Banhazi et al. 2008; Redding 2013). The different gases such as ammonia, carbon dioxide and volatile organic compounds are produced by the decomposition of organic matter with bacteria found in litter and faecal matter (Witkowska and Sowińska 2017). 
The available evidence base illustrates that building design, management practices, age and stocking density of birds along with relative humidity, temperature and ventilation rate can significantly influence emissions from such facilities (Ellen et al. 2000). A range of factors involving building design, use and management can significantly influence emission from such facilities. The availability of data on nature, magnitude and spatio-temporal characteristics of emissions is vital to propose proportionate regulations in order to manage public health risks as well as allowing food production. However, the knowledge on temporal characteristics of emissions from such facilities is limited due to limitations of the sampling methods: labour/time intensive, costly, poor time resolution and considerable post-sampling treatment. Among the wide range of detection and quantification methods, low cost sensors offer realtime data along with portability, affordability and ease of use. These measurements can provide an overview of the dynamics of emissions from poultry facilities and inform further probing into high emission operation and scenarios. Although, there are concerns on data quality (e.g. low accuracy) with low-cost sensors to be used for regulatory compliance, they can offer relative and aggregated information on the state of air quality (Castell et al. 2017; Rai et al. 2017). Several research projects are testing the capabilities of low-cost sensors platforms for air quality monitoring and their findings relay a promising outlook for the use of low-cost sensors, particularly, in providing coarse information and raising community awareness about air pollution (Lewis et al. 2016; Castell et al. 2017; Rai et al. 2017; Morawska et al. 2018).

Poultry farming is a flourishing industry in Pakistan and has shown tremendous progress over the last decade. The sector is playing an important role in fulfilling the demand of protein and has a significant contribution of $1.3 \%$ in national GDP (Maqbool et al. 2005a; Hussain et al. 2015). The sector is an important source of employment and approximately 1.5 million people are associated with this profession (GOP 2014). Moreover, an overall increase in poultry production was noticed in various countries like India, China, Brazil, the United States and Russia from 19952005 (Scanes 2007). However, public health and environmental concerns about emissions (including dust, gases and their bioaerosols) from these facilities are also increasing. At present, information on the concentrations from these facilities is scarce and fundamentally limited by access to state-of-the-art sampling equipment and the resultant methodological challenges. The aim of the present study was to investigate the extent to which low-cost sensors can inform temporal characteristics of particulate and gaseous concentrations from poultry facilities in Lahore, Pakistan.

\section{Material and Methods}


Measurements were conducted in 18 randomly selected environmentally controlled shed (broiler) in outskirts of Lahore, Punjab, Pakistan. The poultry houses were of the same size and build on the same plane as recommended by Cobb guideline for warm regions. Representative design of environmentally control poultry sheds and their building characteristics are presented in Fig. 1 and Table 1.

The information on geographical position, length and width of the farm, total number of fans, number of working fans, number of vents, vents open at particular day, age of bedding material, age of birds, type of feed, number of feeding lines, number of water lines, time and frequency of vaccination of birds and other activities was documented for each site at the time of visit.

The sheds were categorized into three groups according to the age of the birds: group 1(1-20 days), group 2 (2130 days) and group 3 (31-40 days). The particulate matter (PM) fractions $\mathrm{PM}_{2.5}$ and $\mathrm{PM}_{10}$, nitrogen dioxide, hydrogen sulphide, carbon dioxide and methane were monitored in each shed. The measurements for PM and gases were made for both indoor and outdoor but due to a single set of equipment the indoor and outdoor monitoring was not parallel. The sensors were placed at the height of $1.5 \mathrm{~m}$ from the ground level and almost 20-25 $\mathrm{ft}$ away from the exhaust but in the centre according to the width of the shed. Outdoor monitoring was carried out at 15-20 ft away from the side wall of the shed. The particle counter Dylos 1700 was used to measure particle number concentrations of PM. It is a portable particle counter that logs particles in two size classes $(2.5 \mu \mathrm{m}$ and10 $\mu \mathrm{m})$ and records number concentrations. The gases, temperature and relative humidity were monitored by using Aeroqual 500 series sensors and probes. Timeactivity diaries were recorded during the period of monitoring in each shed. The number concentration of PM was converted to mass concentration by using a Dylos conversion sheet (www.fijnstofmeter.com/documentatie/Dylosconversion.pdf). In addition, correction factors were determined for Dylos $1700 \mathrm{PM}_{2.5}$ and $\mathrm{PM}_{10}$ measurements by running it parallel to TSI DRX 8533. The mass concentrations calculated from Dylos 1700 were adjusted with these correction factors.

The data were statistically analyzed using SPSS 21.00 version by Kolmogorov-Smirnov and Levene test that confirmed data was non-parametric. The data was normalized and finally analyzed for parametric tests i.e. one-way ANOVA by Games-Howell post hoc, LSD and Tukey HSD tests. The Kruskal-Wallis test was also applied for appropriate data (emission data for non-activity periods). Moreover, correlation analysis was carried out to examine the relation of indoor and outdoor PM and gases. 


\section{Results}

PM concentrations in broiler houses increased with the age of birds (Table 2 and Fig. 2a). The mean $\mathrm{PM}_{2.5}$ and $\mathrm{PM}_{10}$ concentrations were lowest in group $1\left(0.37 \pm 0.17\right.$ and $\left.4.21 \pm 2.84 \mathrm{mg} / \mathrm{m}^{3}\right)$; however, an increase in group $2(0.70$ \pm 0.44 and $\left.7.66 \pm 4.81 \mathrm{mg} / \mathrm{m}^{3}\right)$ and group $3\left(0.74 \pm 0.35\right.$ and $\left.8.26 \pm 6.13 \mathrm{mg} / \mathrm{m}^{3}\right)$ was observed (Table 2). One way ANOVA showed a statistically significant difference in $\mathrm{PM}_{2.5}$ and $\mathrm{PM}_{10}$ concentrations among all three groups at 0.05 significance level.

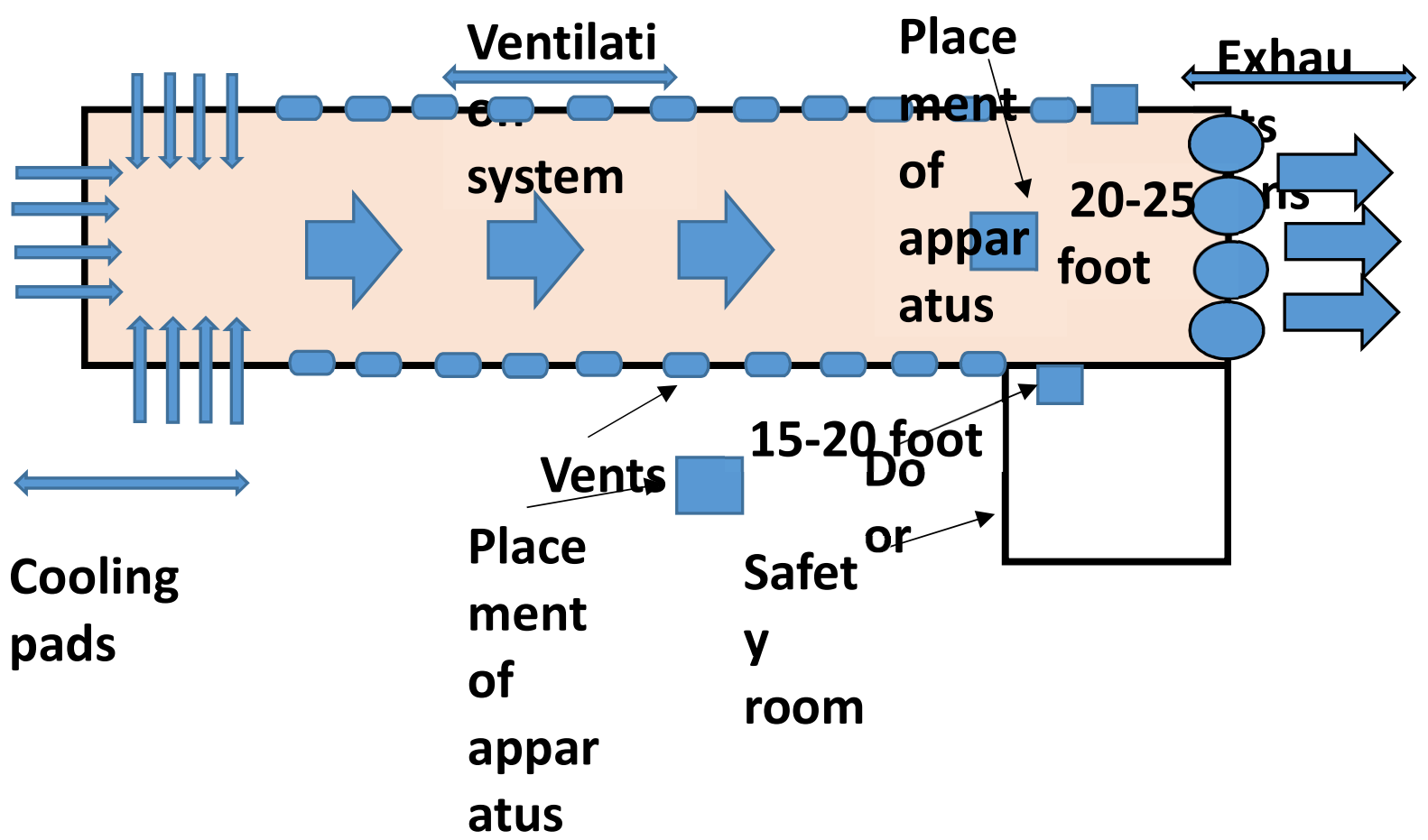

Fig. 1: A representative illustration of the design of an environmentally controlled poultry shed 
Table 1 Building characteristics of the environmentally controlled shed

\begin{tabular}{|l|l|l|l|l|l|l|l|}
\hline Size & $\begin{array}{l}\text { No of } \\
\text { birds }\end{array}$ & Orientation & Side walls & Roof & $\begin{array}{l}\text { Heating } \\
\text { system }\end{array}$ & $\begin{array}{l}\text { Ventilation } \\
\text { system }\end{array}$ & Lighting \\
\hline $\begin{array}{l}5,715 \\
\mathrm{~m}^{3}\end{array}$ & $\begin{array}{l}26,500- \\
30,000\end{array}$ & $\begin{array}{l}\text { long axis } \\
\text { oriented east- } \\
\text { west }\end{array}$ & $\begin{array}{l}\text { Filled with } \\
\text { insulating } \\
\text { materials }\end{array}$ & $\begin{array}{l}\text { Reflective } \\
\text { materials to } \\
\text { prevent heat } \\
\text { absorbance } \\
\text { by } \\
\text { conduction }\end{array}$ & $\begin{array}{l}\text { A well- } \\
\text { maintained } \\
\text { heating } \\
\text { system } \\
\text { present in } \\
\text { each site but } \\
\text { not working } \\
\text { at the time of } \\
\text { visit }\end{array}$ & $\begin{array}{l}\text { A nentilation } \\
\text { system working } \\
\text { to bring fresh air } \\
\text { and removal of } \\
\text { stale air }\end{array}$ & $\begin{array}{l}\text { The } \\
\text { lighting } \\
\text { system } \\
\text { was } \\
\text { present }\end{array}$ \\
& & & & & \\
\end{tabular}

to activate the birds) in comparison to no activity periods (Fig. 2b). The mean $\mathrm{PM}_{2.5}$ and $\mathrm{PM}_{10}$ concentrations at the time of activity for group 1 were $0.58 \pm 0.15$ and $8.32 \pm 5.77 \mathrm{mg} / \mathrm{m}^{3}$ respectively whereas, for group 2 and 3 , these were $0.96 \pm 0.21,16.2 \pm 6.5$ and $0.98 \pm 0.31,13.16 \pm 5.77 \mathrm{mg} / \mathrm{m}^{3}$, respectively (Table 2). In contrast, the concentration of $\mathrm{PM}_{2.5}$ and $\mathrm{PM}_{10}$ during no activity was $0.31 \pm 0.8$ and $3.13 \pm 2.5 \mathrm{mg} / \mathrm{m}^{3}$ respectively for group $1,0.59 \pm 0.5$ and 5.35 $\pm 4.2 \mathrm{mg} / \mathrm{m}^{3}$ for group 2 and $0.63 \pm 0.3$ and $5.73 \pm 4.7 \mathrm{mg} / \mathrm{m}^{3}$ for group 3, respectively. For the concentrations, during activities, a statistically significant difference in $\mathrm{PM}_{2.5}$ and $\mathrm{PM}_{10}$ concentrations was noticed for group 1 with group 2 and group 3, but no difference was found between group 2 and group 3. However, for the non-activity periods, a significant difference was present among all the three groups.

The average concentration of $\mathrm{PM}_{2.5}$ for outdoor environment was $0.07,0.22$ and $0.12 \mathrm{mg} / \mathrm{m}^{3}$ for group 1,2 and 3, respectively. While the $\mathrm{PM}_{10}$ concentration was $0.35,0.81$ and $0.42 \mathrm{mg} / \mathrm{m}^{3}$ for group 1,2 and 3, respectively (Table 2). A significant difference for outdoor concentrations of $\mathrm{PM}_{2.5}$ was present among all the groups. However, for the $\mathrm{PM}_{10}$ a significant difference was noticed in group 1 with group 2 and group 3 but no difference was found between group 2 and group 3. The Pearson correlation showed that $\mathrm{PM}_{2.5}$ and $\mathrm{PM}_{10}$ had a positive relationship between the indoor and outdoor environments of group 1 and group 2 (only for $\mathrm{PM}_{2.5}$ ). An inverse relation was present between indoor and outdoor environment for group 2 and group 3 at 0.01 significant levels. 
Table 2 Summary concentration of particulate matter $\left(\mathrm{mg} / \mathrm{m}^{3}\right)$ in poultry farm categories and outdoors

\begin{tabular}{lllll}
\hline PM concentrations scenario & $\begin{array}{l}\text { Group 1 } \\
\text { Mean }( \pm \text { SD) } \\
\left(\mathrm{mg} / \mathrm{m}^{3}\right)\end{array}$ & $\begin{array}{l}\text { Group 2 } \\
\text { Mean }( \pm \text { SD) } \\
\left(\mathrm{mg} / \mathrm{m}^{3}\right)\end{array}$ & $\begin{array}{l}\text { Group 3 } \\
\text { Mean }( \pm \text { SD }) \\
\left(\mathrm{mg} / \mathrm{m}^{3}\right)\end{array}$ \\
\hline Indoor Total & PM2.5 & $0.37( \pm 0.17)$ & $0.70( \pm 0.44)$ & $0.74( \pm 0.35)$ \\
Activity & PM10 & $4.21( \pm 2.84)$ & $7.66( \pm 4.81)$ & $8.26( \pm 6.13)$ \\
\multirow{2}{*}{ Non- Activity } & PM2.5 & $0.58( \pm 0.15)$ & $0.96( \pm 0.21)$ & $0.98( \pm 0.31)$ \\
& PM10 & $8.32( \pm 5.77)$ & $16.2( \pm 6.5)$ & $13.16( \pm 5.77)$ \\
Outdoor & PM2.5 & $0.31( \pm 0.8)$ & $0.59( \pm 0.5)$ & $0.63( \pm 0.3)$ \\
& PM10 & $3.13( \pm 2.5)$ & $5.35( \pm 4.2)$ & $5.73( \pm 4.7)$ \\
& PM2.5 & $0.07( \pm 0.06)$ & $0.22( \pm 0.04)$ & $0.12( \pm 0.06)$ \\
\hline
\end{tabular}

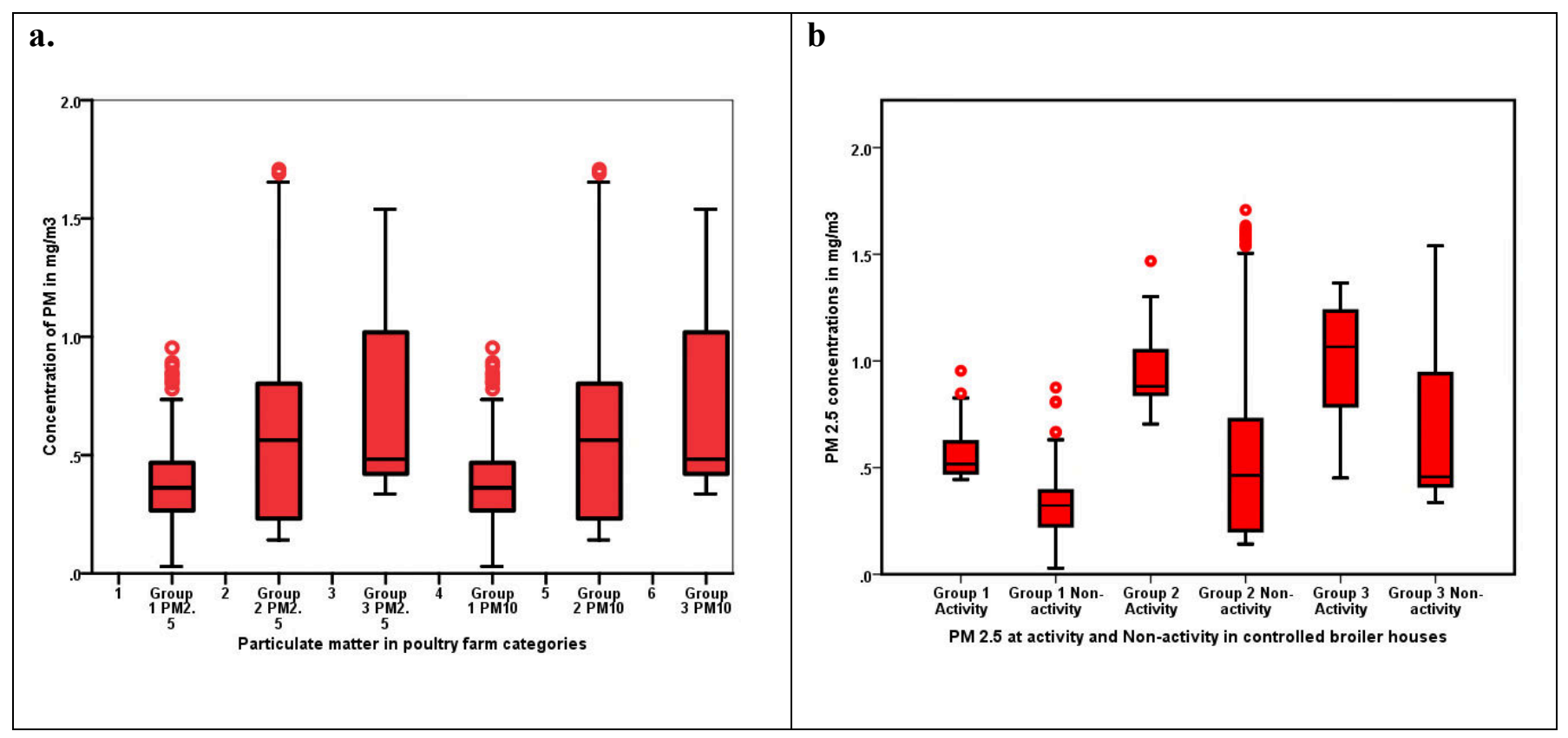




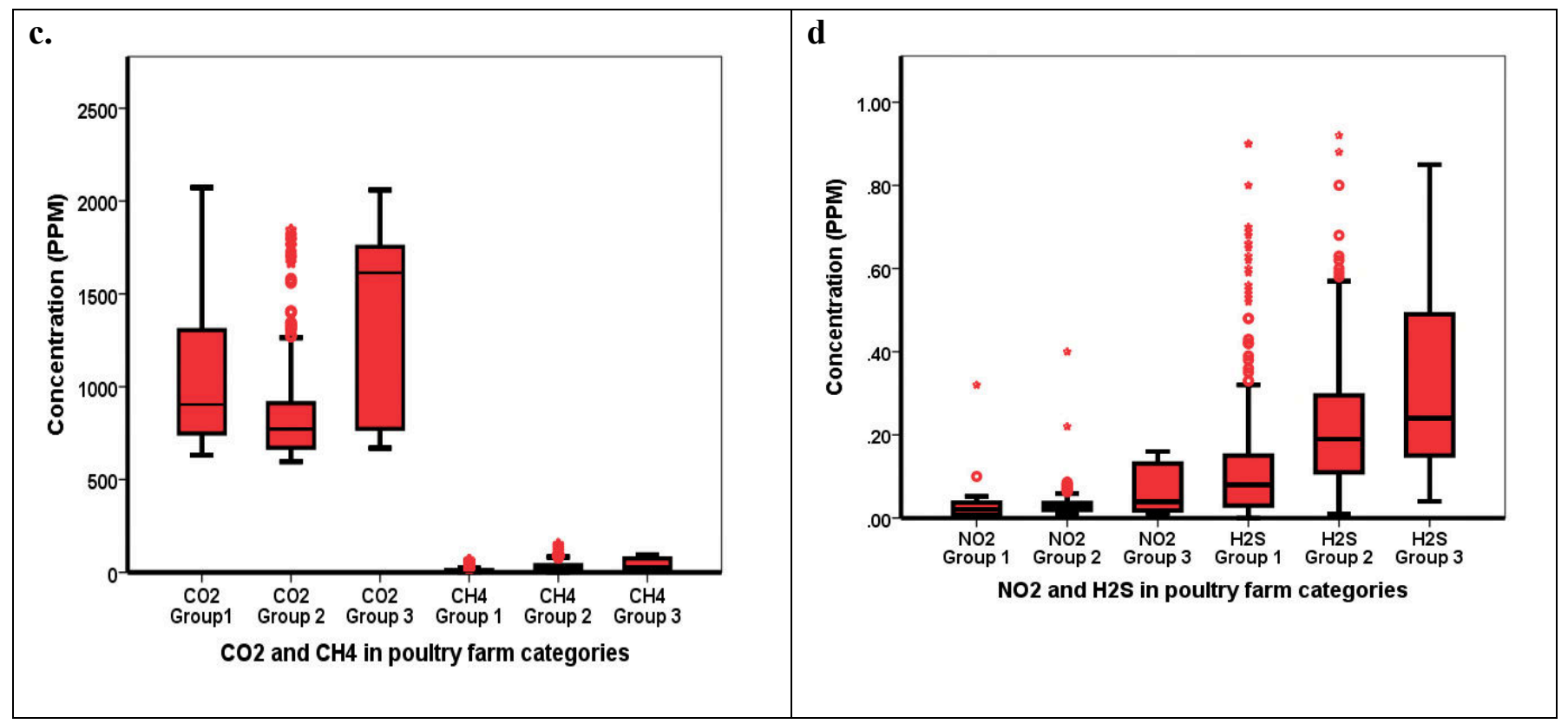

Figure 2: Summary statistics of particulate matter and gaseous emissions from poultry farm categories. a Particulate matter. b Particulate matter during the activity and non-activity time. $\mathrm{CO}_{2}$ and $\mathrm{CH}_{4}, \mathrm{~d} \mathrm{NO}_{2}$ and $\mathrm{H}_{2} \mathrm{~S}$

The relative humidity and temperature ranged between 51 and $60 \%$ and $31-34{ }^{\circ} \mathrm{C}$ for indoors, while, for outdoors relative humidity and temperature were $32-33 \%$ and $37-41{ }^{\circ} \mathrm{C}$. Relative humidity had an inverse relation with $\mathrm{PM}_{2.5}$ and $\mathrm{PM}_{10}$ at a 0.05 significance level but a positive relation was seen with all monitored gases. All gaseous concentrations showed an increase with age of birds in different poultry farm categories (Fig. 2c, d). The average concentration for $\mathrm{NO}_{2}$ and $\mathrm{H}_{2} \mathrm{~S}$ gases ranged between $0.02-0.06$ and $0.14-0.32$ ppm for group 1,2 and 3 respectively. The second most abundant gas was $\mathrm{CH}_{4}: 15.55,31.88$ and 41.64 ppm in group 1, 2 and 3 respectively (Table 3).The levels of $\mathrm{CO}_{2}$ were $868 \pm 201,1005 \pm 340$ and $1706 \pm 199 \mathrm{ppm}$ for group 1,2 and 3 respectively (Table 3 ).

In outdoors, the concentrations of different gases for groups 1,2 and 3 were: $\mathrm{NO}_{2}: 0.09,0.05,0.28 \mathrm{ppm}$, $\mathrm{H}_{2} \mathrm{~S}: 0.41,0.07$ and $0.02 \mathrm{ppm}, \mathrm{CH}_{4}: 1.93,42.22$ and $5.61 \mathrm{ppm}, \mathrm{CO}_{2}: 488,435$ and $548 \mathrm{ppm}$, respectively. The gaseous concentrations in outdoors showed no trend according to age groups or effect of indoor emissions highlighting additional sources to indoor emissions. A significant difference in all indoor and outdoor gases was present at 0.05 levels among all groups except outdoor $\mathrm{CO}_{2}$ and $\mathrm{H}_{2} \mathrm{~S}$ (Table 3). 
Pearson correlation revealed that indoor and outdoor $\mathrm{CO}_{2}$ in group $1(0.52)$ and $3(0.30)$ were positively correlated at 0.01 . However, a negative correlation was present for group $2(-0.30)$. There was an inverse correlation for $\mathrm{NO}_{2}$ in group 1 (-.19) and 3 (-0.29) while a very weak correlation was observed for group $2(0.08)$. A positive correlation was present among all groups for $\mathrm{CH}_{4}$ and $\mathrm{H}_{2} \mathrm{~S}$.

Table 3: Summary concentrations (ppm) of different gases in poultry farm categories and outdoors

\begin{tabular}{|c|c|c|c|c|c|c|}
\hline \multirow{3}{*}{$\begin{array}{l}\text { Gases } \\
\text { (ppm) }\end{array}$} & \multicolumn{3}{|l|}{ Indoor } & \multicolumn{3}{|l|}{ Outdoor } \\
\hline & Group 1 & Group 2 & Group 3 & Group 1 & Group 2 & Group 3 \\
\hline & Mean \pm SD & $\operatorname{Mean} \pm \mathrm{SD}$ & Mean \pm SD & Mean \pm SD & Mean \pm SD & $\operatorname{Mean} \pm \mathrm{SD}$ \\
\hline $\mathrm{NO}_{2}$ & $0.02 \pm 0.02$ & $0.03 \pm 0.03$ & $0.06 \pm 0.05$ & $0.10 \pm 0.12$ & $0.06 \pm 0.03$ & $0.29 \pm 0.35$ \\
\hline $\mathrm{CH}_{4}$ & $15.5 \pm 15.2$ & $31.9 \pm 32.6$ & $41.6 \pm 29.0$ & $1.93 \pm 1.51$ & $42.2 \pm 107.2$ & $5.62 \pm 7.75$ \\
\hline $\mathrm{H}_{2} \mathrm{~S}$ & $0.14 \pm 0.2$ & $0.22 \pm 0.2$ & $0.32 \pm 0.2$ & $0.42 \pm 0.76$ & $0.08 \pm 0.09$ & $0.02 \pm 0.02$ \\
\hline $\mathrm{CO}_{2}$ & $868 \pm 201$ & $1005 \pm 340$ & $1706 \pm 199$ & $488 \pm 71$ & $434 \pm 16$ & $547 \pm 189$ \\
\hline
\end{tabular}

\section{Discussion}

The intensive agriculture facilities are a source of the odour, dust, allergens, bacteria, viruses, fungi, toxins along with gases like $\mathrm{CH}_{4}, \mathrm{H}_{2} \mathrm{~S}, \mathrm{NO}_{2}, \mathrm{CO}_{2}$ and various trace gases (Copeland 2010). In the present study, the concentrations of PM were corrected using the reference method and TSI DRX 8533 was run parallel to Dylos 1700 . However, the results obtained for both fractions of PM were comparable with a number of studies (Conceicao et al. 1989; Ellen et al. 2000; Lim et al. 2003; Al Homidan et al. 2004). This showed that the result of low cost sensors such as Dylos 1700 can be reliable and can be used to get an estimation of particulate matter.

Overall, it was noticed the poultry sector is flourishing from the last few decades to fulfil a gap between demand and supply. Approximately, 1.5 million people are also affiliated with the sector (Hussain et al. 2015). Furthermore, technologies becoming advanced day by day and an increase in the use of real-time sensors to improve animal safety and production are also observed, as these sensors seem to be helpful and alert the cattle farmers before time by the early indication of medical problems (Halachmi et al. 2019). Although, several research projects are testing the capabilities of low cost sensors for air quality monitoring and their findings relay a promising outlook for the use of low cost sensors. At present, these sensor systems have demonstrated their usefulness for providing information 
and raising community awareness about air pollution (Lewis et al. 2016; Castell et al. 2017; Rai et al. 2017; Morawska et al. 2018).

In the present study, the $\mathrm{PM}_{2.5}$ and $\mathrm{PM}_{10}$ concentrations increased with age of birds and this trend is in agreement with Le Bouquin et al. (2013), Burns et al. (2009) and Zhang et al. (2019) who reported the age of birds acts as a determinant factor for PM concentrations along litter management practices and temperature. Similarly, Redwine et al. (2002) had also reported age enhanced PM and ammonia emissions. The present study also demonstrated that activities in controlled environment facilities result in higher concentration of dust as also reported by Lim et al. (2003), Vucemilo et al. (2007), Li et al. (2009), Calvet et al. (2009) and Shen et al. (2019) and that the airborne dust in poultry houses increased with the age and activity of birds.

In the current study, the mass concentration of coarse particles $\left(\mathrm{PM}_{10}\right)$ was higher as compared with fine particles $\left(\mathrm{PM}_{2.5}\right)$ and this trend had been recorded in previous studies elsewhere as well. Cambra-Lopez et al. (2010a, b) have reported that in poultry facilities feathers and manure contribute mostly to $\mathrm{PM}_{10}$ concentrations compared to $\mathrm{PM}_{2.5}$. Similarly, according to Casey et al. (2006), the most probable sources for PM concentrations in controlled environment facilities were feed, faecal material, bird's skin and feathers along with bedding material.

These finding can inform the development of need-based appropriate emission control technologies as well as strategies. It has been reported that the relative humidity $(\mathrm{RH})$ can play a role to control particulate emissions in the environmentally controlled facilities to reduce the risk of exposure to both birds and employees Corkery et al. (2013). In the current study, $\mathrm{RH}$ was between 50 and $60 \%$ and it showed an inverse relation with both fractions of $\mathrm{PM}\left(\mathrm{PM}_{2.5}\right.$ and $\mathrm{PM}_{10}$ ) and temperature with a 0.01 significance level. The particulate and gaseous concentrations in controlledenvironment facilities are strongly related to ventilation rate, the age of birds, the activity of birds and management practices. The role of facility management, particularly, ventilation rate is very important for the control of heat, humidity, PM and gases as reported by many studies (Roumeliotis and Heyst 2007; Kocaman et al. 2005, 2006; Broucek and Cermak 2015).

It was also seen that concentrations of $\mathrm{NO}_{2}$ and $\mathrm{H}_{2} \mathrm{~S}$ were low as compared with those of $\mathrm{CH}_{4}$ and $\mathrm{CO}_{2}$ as shown in Fig. 2c, d. The $\mathrm{H}_{2} \mathrm{~S}$ is produced by anaerobic decomposition of sulphate-containing organic compounds present in manure and causes respiratory problems when present in high concentrations (Barrasa et al. 2012). 
Wang et al. (2011) mentioned $100 \%$ mortality rate in Leghorn males (breed of chicken) when exposed to $4000 \mathrm{mg} / \mathrm{kg}$ of hydrogen sulphide for 15 minutes and exposure of $2 \mathrm{mg} / \mathrm{kg}$ was recommended as least toxic. The maximum production of hydrogen sulphide in the present study was $0.14-0.20 \mathrm{ppm}$ for group 1 to 3 (Table 3), and the average concentrations reported by (Barrasa et al. 2012) for $\mathrm{H}_{2} \mathrm{~S}$ was $0.10 \mathrm{ppm}$ in fattening broilers houses which is lower than that in the present study. The concentration of $\mathrm{NO}_{2}(0.02-0.06 \mathrm{ppm})$ among all three groups were slightly higher as compared to $\mathrm{NO}_{2}$ concentrations $(0.01$ and $0.02 \mathrm{ppm})$ reported by Almuhanna et al. (2011) in two mechanically ventilated poultry houses in Al-Ahsa, Saudi Arabia, for a complete growth cycle. There is a scarcity of data on $\mathrm{NO}_{2}$ emission in poultry farms. The most published data is for ammonia and nitrous oxide.

The main sources of $\mathrm{CH}_{4}$ in these environments are manure storage practices and decomposition of organic matter; however, a small amount can be produced due to the monogastric digestive physiology of birds (Broucek and Cermak 2015).The range of $\mathrm{CH}_{4}$ concentrations (15.5-42.2 ppm) measured in the current study showed a significant increase among the groups, and levels were higher as compared with $2.56 \mathrm{ppm}$ (Winter) to $15.68 \mathrm{ppm}$ (summer)) in broiler houses in Bursa, northwest of Turkey (Kilic and Yaslioglu 2013). A study designed in a respiration chamber by Wang and Huang (2005) for investigation of poultry enteric fermentation reported an estimated emission factor of $15.87 \mathrm{mg}_{\text {bird }}{ }^{-1}$ life cycle ${ }^{-1}$ for $\mathrm{CH}_{4}$. Methane and carbon dioxide have the ability to displace oxygen and can cause suffocation in controlled environments (Barrasa et al. 2012). Carbon dioxide was the highest concentration gas recorded in this study. Its production depends on stocking density of birds, the age of birds, the activity of birds, type of feed, consumption rate and temperature. Additionally, decomposition and moisture level of bedding material and management practices, such as the ventilation rate of the building, also plays a role in determining $\mathrm{CO}_{2}$ levels in poultry sheds. The recommended levels for $\mathrm{CO}_{2}$ in poultry houses should be less than $5500 \mathrm{mg} / \mathrm{m}^{3}$ (Council Directive 2007/43/EC, 2007). The $\mathrm{CO}_{2}$ concentrations in the present study were $883-1706 \mathrm{ppm}\left(1170-3306 \mathrm{mg} / \mathrm{m}^{3}\right)$ and increased with the age of the birds (Table 3). Barrasa et al. (2012) reported the highest level of $\mathrm{CO}_{2}$ with the largest variation during the monitoring period in poultry houses as compared with cattle and pig farms, and the production of all gases generally increased with the age of birds (Calvet et al. 2011). Ventilation rate has been reported to significantly impact the level of indoor $\mathrm{CO}_{2}$ concentrations in poultry facilities. A study conducted in a tunnelventilated commercial broiler house by Broucek and Cermak (2015) has shown $\mathrm{CO}_{2}$ emissions increased with the age of birds and an inverse correlation was observed between ventilation rate and $\mathrm{CO}_{2}$ concentrations. It was noticed in the present study that poultry facilities could be a higher source of PM and gases in comparison to other intensive 
agricultural facilities. Herron et al. (2015) also reported poultry facilities were found as more contaminated sites as compared to other livestock units (cow and swine farms). The poultry facilities were also rich in organic dust and may cause various health problems (Donham et al. 2000; Portejoie et al. 2002; Donham et al. 2002; Kocaman et al. 2005; Oppliger et al. 2008; Skora et al. 2016; Li et al. 2019; Shen et al. 2019). Enforcement of the existing occupational health and safety laws (for example, the use of PPE) and good management practices can significantly reduce the risk of exposure to poultry workers.

The outdoor sampling carried out for the PM and gaseous concentrations revealed a correlation with indoor levels in the majority of cases, but an inverse relation was also seen showing outdoor environment was least affected by indoor emissions. The levels in outdoors seem to depend on wind speed/direction and various other factors such as feed storage houses, leftover of bedding materials, vegetation, use of fertilizer on particular days and other high energy activities in the surroundings. A study by Shen et al. (2018) showed that $\mathrm{PM}_{10}$ and TSP were significantly higher inside poultry house compared with the outside.

\section{Conclusions}

The knowledge on spatio-temporal characteristics of concentrations from intensive poultry facilities is vital to better understand the nature and magnitude of these emissions and their potential public and environmental health impact. Recent advancements in sensor technologies have resulted in the development of a range of lower cost sensors for particulate and gaseous air pollution monitoring. In the present study, age of the birds was a predominant factor for the increased PM and gaseous concentrations, along with the fact that the concentrations of both were found higher during different activities in comparison with non-activity periods. The outdoor concentrations in the vicinity of these facilities were not solely dependent on indoor emissions and might have different additional external sources. There is potential in low-cost sensors such as Dylos 1700 and Aeroqual 500 series used in this study to provide overview trends in spatio-temporal concentrations from such facilities for non-regulatory applications. In particular, these can identify high emission activities and time periods over the growth cycle of birds. However, the data presented in this study provide a snapshot view of particulate and gaseous concentrations from poultry facilities. Further studies are needed to improve understanding of the nature and magnitude of the emission from poultry facilities and their resultant health and environmental impact. Key attention should be given to the chemical and biological characterisation of 
particulate emissions, in particular, cellular responses associated with biological molecules such as endotoxin emitted from poultry facilities.

Acknowledgements: Roheela Yasmeen's research visit at Cranfield University was supported by the Higher Education Commission Pakistan under International Research Support Initiative Programme.

\section{References}

Al-Homidan, A. (2004). SPRING MEETING OF THE WPSA UK BRANCH POSTERS: Effect of temperature and light regimen on ammonia, dust concentrations and broiler performance. British poultry science 45(1), 35-36.

Almuhanna E. A, Ahmed, A. S., \& Al-Yousif, Y. M. (2011). Effect of air contaminants on poultry immunological and production performance. International Journal of Poultry Science, 10(6), 461-470.

Banhazi, T. M., Seedorf, J., Laffrique, M., \& Rutley, D. L. (2008). Identification of the risk factors for high airborne particle concentrations in broiler buildings using statistical modelling. Biosystems Engineering, 101(1), 100 110 .

Barrasa, M., Lamosa, S., Fernandez, M. D., \& Fernandez, E. (2012). Occupational exposure to carbon dioxide, ammonia and hydrogen sulphide on livestock farms in north-West Spain. Annals of Agricultural and Environmental Medicine, 19(1), 17-24.

Broucek, J., \& Cermak, B. (2015). Emission of harmful gases from poultry farms and possibilities of their reduction. Ekologia, 34(1), 89-100.

Burns, R. T., Li, H., Moody, L., Xin, H., Gates, R., Overhults, D., \& Earnest, J. (2009). Quantification of particulate emissions from broiler houses in the southeastern United States. In In livestock environment VIII (p. 15). Iguassu Falls, Brazil: ASABE Publication Number 701P0408.

Calvet, S., Van den Weghe, H., Kosch, R., \& Estellés, F. (2009). The influence of the lighting program on broiler activity and dust production. Poultry Science, 88(12), 2504-2511.

Calvet, S., Cambra-López, M., Estelles, F., \& Torres, A. G. (2011). Characterization of gas emissions from a Mediterranean broiler farm. Poultry Science, 90(3), 534-542.

Cambra-López, M., Aarnink, A. J., Zhao, Y., Calvet, S., \& Torres, A. G. (2010a). Airborne particulate matter from livestock production systems: a review of an air pollution problem. Environmental Pollution, 158(1), 1-17.

Cambra-López, M., Hermosilla, T., Lai, H. T., Montero, M., Aarnink, A. J., Ogink, N. W. (2010b). Source identification and quantification of particulate matter emitted from livestock houses. In International Symposium on Air Quality and Manure Management for Agriculture Conference Proceedings Dallas, Texas (p. 41). American Society of Agricultural and Biological Engineers.

Cambra-López, M., Hermosilla, T., Lai, H. T., Aarnink, A. J., \& Ogink, N. W. M. (2011). Particulate matter emitted from poultry and pig houses: source identification and quantification. Transactions of the ASABE, 54(2), 629-642.

Casey, K. D., Bicudo, J. R., Schmidt, D. R., Singh, A., Gay, S. W., Gates, R. S., \& Hoff, S. J. (2006). Air quality and emissions from livestock and poultry production/waste management systems (pp. 1-40). ASABE. https://doi.org/10.13031/2013.20246.

Castell, N., Dauge, F. R., Schneider, P., Vogt, M., Lerner, U., Fishbain, B., et al. (2017). Can commercial low-cost sensor platforms contribute to air quality monitoring and exposure estimates? Environment International, 99 , 293-302. 
Chen, J., Qiu, S., Shang, J., Wilfrid, O. M., Liu, X., Tian, H., \& Boman, J. (2014). Impact of relative humidity and water soluble constituents of PM2.5 on visibility impairment in Beijing, China. Aerosol and Air Quality Research, 14, 260-268.

Clements, A. L., Griswold, W. G., Rs, A., Johnston, J. E., Herting, M. M., Thorson, J., \& Hannigan, M. (2017). Lowcost air quality monitoring tools: from research to practice (a workshop summary). Sensors, 17(11), 2478.

Conceicao, M. A. P., Johnson, H. E., \& Wathes, C. M. (1989). Air hygiene in a pullet house: Spatial homogeneity of aerial pollutants. British Poultry Science, 30(4), 765-776.

Copeland C (2010). Air quality issues and animal agriculture: A primer. In The CRS report for congress (pp. 1-34).

Corkery, G., Ward, S., Kenny, C., Hemmingway, P. (2013). Monitoring environmental parameters in poultry production facilities. In Computer Aided Process Engineering-CAPE Forum 2013, 2013. Institute for Process and Particle Engineering, Graz University of Technology, Austria.

Donham, K. J., Cumro, D., Reynolds, S. J., \& Merchant, J. A. (2000). Dose-response relationships between occupational aerosol exposures and cross-shift declines of lung function in poultry workers:: recommendations for exposure limits. Journal of Occupational and Environmental Medicine, 42(3), 260269.

Donham, K. J., Cumro, D., \& Reynolds, S. (2002). Synergistic effects of dust and ammonia on the occupational health effects of poultry production workers. Journal of Agromedicine, 8(2), 57-76.

Ellen, H. H., Bottcher, R. W., Von Wachenfelt, E., \& Takai, H. (2000). Dust levels and control methods in poultry houses. Journal of Agricultural Safety and Health, 6(4), 275-282.

EMEP-CORINAIR. (2007). EMEP/CORINAIR atmospheric emission inventory guidebook. December 2007 Update (third ed.). Copenhagen: EEA.

GOP (Government of Pakistan) Economic survey of Pakistan (2014), Ministry of Finance, http://www.finance.gov. pk/survey/chapters_14/02_Agriculture.pdf.

Halachmi, I., Guarino, M., Bewley, J., \& Pastell, M. (2019). Smart animal agriculture: application of real-time sensors to improve animal well-being and production. Annual Review of Animal Biosciences, 7, 403-425.

Herron, S. L., Brye, K. R., Sharpley, A. N., Miller, D. M., \& Daniels, M. B. (2015). Nutrient composition of dust emitted from poultry broiler houses in Northwest Arkansas. Journal of Environmental Protection, 6(11), 1257.

Hinz, T., Linke, S., Eisenschmidt, R., Muller, H. J., \& Bobrutzki, K. V. (2008). Small scale dispersion of ammonia around animal husbandries. Landbauforschung Völkenrode, 58(1), 295-305. Homidan, A. A., Robertson, J. F., \& Petchey, A. M. (2003). Review of the effect of ammonia and dust concentrations on broiler performance. World's Poultry Science Journal, 59(3), 340-349.

Hussain, J., Rabbani, I., Aslam, S., \& Ahmad, H. A. (2015). An overview of poultry industry in Pakistan. World's Poultry Science Journal, 71(4), 689-700.

Kilic, I., \& Yaslioglu, E. (2013). Agricultural development within the rural-urban continuum. Environmental emission from broiler houses in Bursa. Turkey, 16059: http://www. tropentag.de/2013/abstracts/links/Kilic_flt4zHNF.pdf.

Kocaman, B., Yaganoglu, A. V., \& Yanar, M. (2005). Combination of fan ventilation system and spraying of oilwater mixture on the levels of dust and gases in caged layer facilities in Eastern Turkey. Journal of Applied Animal Research, 27(2), 109-111.

Kocaman, B., Esenbuga, N., Yildiz, A., Lacin, E., \& Macit, M. (2006). Effect of environmental conditions in poultry houses on the performance of laying hens. International Journal of Poultry Science, 5(1), 26-30. 
Le Bouquin, S., Huneau-Salaun, A., Huonnic, D., Balaine, L., Martin, S., \& Michel, V. (2013). Aerial dust concentration in cage-housed, floor-housed, and aviary facilities for laying hens. Poultry Science, 92(11), 2827-2833.

Lewis AC, Lee JD, Edwards PM, Shaw MD, Evans MJ, Moller SJ, ... White A (2016). Evaluating the performance of low cost chemical sensors for air pollution research. Faraday Discussions 189: 85-103.

Li, H., Xin, H., Burns, R. T., Hoff, S. J., Harmon, J. D., Jacobson, L. D., \& Noll, S. L. (2009). Effects of bird activity, ventilation rate and humidity on PM10 concentration and emission rate of a Turkey barn. In livestock environment VIII, 31 August-4 September 2008 (p. 16). Iguassu Falls, Brazil: American Society of Agricultural and Biological Engineers.

Li, Z., Zheng, W., Wei, Y., Li, B., Wang, Y., \& Zheng, H. (2019). Prevention of particulate matter and airborne culturable bacteria transmission between double-tunnel ventilation layer hen houses. Poultry Science, 98(6), 2392-2398.

Lim, T. T., Heber, A. J., Ni, J. Q., Gallien, J. X., \& Xin, H. (2003). Air quality measurements at a laying hen house: Particulate matter concentrations and emissions. In In air pollution from agricultural operations-III (p. 249). American Society of Agricultural and Biological Engineers.

Maqbool, A., Bakhsh, K., Hassan, I., Chattha, M. W. A., \& Ahmad, A. S. (2005). Marketing of commercial poultry in Faisalabad city (Pakistan). Journal of Agriculture and Social Sciences, 1(4), 327-331.

Mitchell, B. W., Richardson, L. J., Wilson, J. L., \& Hofacre, C. L. (2004). Application of an electrostatic space charge system for dust, ammonia, and pathogen reduction in a broiler breeder house. Applied Engineering in Agriculture, 20(1), 87-93.

Morawska L, Thai PK, Liu X, Asumadu-Sakyi A, Ayoko G, Bartonova A, ... Gao J (2018). Applications of low-cost sensing technologies for air quality monitoring and exposure assessment: how far have they gone? Environment International 116: 286-299.

Mostafa, E., \& Buescher, W. (2011). Indoor air quality improvement from particle matters for laying hen poultry houses. Biosystems Engineering, 109(1), 22-36.

Oppliger, A., Charrière, N., Droz, P. O., \& Rinsoz, T. (2008). Exposure to bioaerosols in poultry houses at different stages of fattening; use of real-time PCR for airborne bacterial quantification. Annals of Occupational Hygiene, 52(5), 405-412.

Pope, C. A., III, Burnett, R. T., Thun, M. J., Calle, E. E., Krewski, D., Ito, K., \& Thurston, G. D. (2002). Lung cancer, cardiopulmonary mortality, and long-term exposure to fine particulate air pollution. JAMA, 287(9), 11321141 .

Portejoie, S., Martinez, J., \& Landmann, G. (2002). Ammonia of farm origin: Impact on human and animal health and on the natural habitat. Productions Animales (France) http://agris. fao.org/agrissearch/search.do?recordID=FR2002003459.

Radon, K., Weber, C., Iversen, M., Danuser, B., Pedersen, S., \& Nowak, D. (2001). Exposure assessment and lung function in pig and poultry farmers. Occupational and Environmental Medicine, 58(6), 405-410.

Rai, A. C., Kumar, P., Pilla, F., Skouloudis, A. N., Di Sabatino, S., Ratti, C., ... Rickerby, D. (2017). End-user perspective of low-cost sensors for outdoor air pollution monitoring. Science of The Total Environment 607: 691-705.

Redding, M. R. (2013). Bentonite can decrease ammonia volatilisation losses from poultry litter: laboratory studies. Animal Production Science, 53(10), 1115-1118.

Redwine, J. S., Lacey, R. E., Mukhtar, S., \& Carey, J. B. (2002). Concentration and emissions of ammonia and particulate matter in tunnel-ventilated broiler houses under summer conditions in Texas. Transactions of the ASAE, 45(4), 1101. 
Roumeliotis, T. S., \& Van Heyst, B. J. (2007). Size fractionated particulate matter emissions from a broiler house in Southern Ontario, Canada. Science of the Total Environment, 383(1-3), 174-182.

Scanes, C.G. (2007). The global importance of poultry. 1057- 1058.

Shen, D., Wu, S., Dai, P. Y., Li, Y. S., \& Li, C. M. (2018). Distribution of particulate matter and ammonia and physicochemical properties of fine particulate matter in a layer house. Poultry Science, 97(12), 4137-4149.

Shen, D., Wu, S., Li, Z., Tang, Q., Dai, P., Li, Y., \& Li, C. (2019). Distribution and physicochemical properties of particulate matter in swine confinement barns. Environmental Pollution, 250, 746-753.

Skora, J., Matusiak, K., Wojewódzki, P., Nowak, A., Sulyok, M., Ligocka, A., Okrasa, M., Hermann, J., \& Gutarowska, B. (2016). Evaluation of microbiological and chemical contaminants in poultry farms. International Journal of Environmental Research and Public Health, 13(2), 192.

van Harn, J., Aarnink, A. J. A., Mosquera, J., Van Riel, J. W., \& Ogink, N. W. M. (2012). Effect of bedding material on dust and ammonia emission from broiler houses. Transactions of the ASABE, 55(1), 219-226. Vucemilo, M., Matkovic, K., Vinkovic, B., Jaksic, S., Granic, K., \& Mas, N. (2007). The effect of animal age on air pollutant concentration in a broiler house. Czech Journal of Animal Science, 52(6), 170-174.

Vucemilo M, Matkovic K, Vinkovic B, Macan J, Varnai VM, Prester LJ, ... Orct T (2008). Effect of microclimate on the airborne dust and endotoxin concentration in a broiler house. Czech Journal of Animal Science, 53(2): 83-9.

Wang, S. Y., \& Huang, D. J. (2005). Assessment of greenhouse gas emissions from poultry enteric fermentation. Asian-Australasian Journal of Animal Sciences, 18(6), 873-878.

Wang, Y., Huang, M., Meng, Q., \& Wang, Y. (2011). Effects of atmospheric hydrogen sulfide concentration on growth and meat quality in broiler chickens. Poultry Science, 90(11), 2409-2414.

Witkowska, D., \& Sowinska, J. (2017). Identification of microbial and gaseous contaminants in poultry farms and developing methods for contamination prevention at the source. In Poultry science. InTech.

Zhang, J., Wei, X., Jiang, L., Li, Y., Li, M., Zhu, H., Yu, X., Tang, J., Chen, G., \& Zhang, X. (2019). Bacterial community diversity in particulate matter (PM2. 5 and PM10) within broiler houses in different broiler growth stages under intensive rearing conditions in summer. The Journal of Applied Poultry Research, 28(2), 479-489. 